
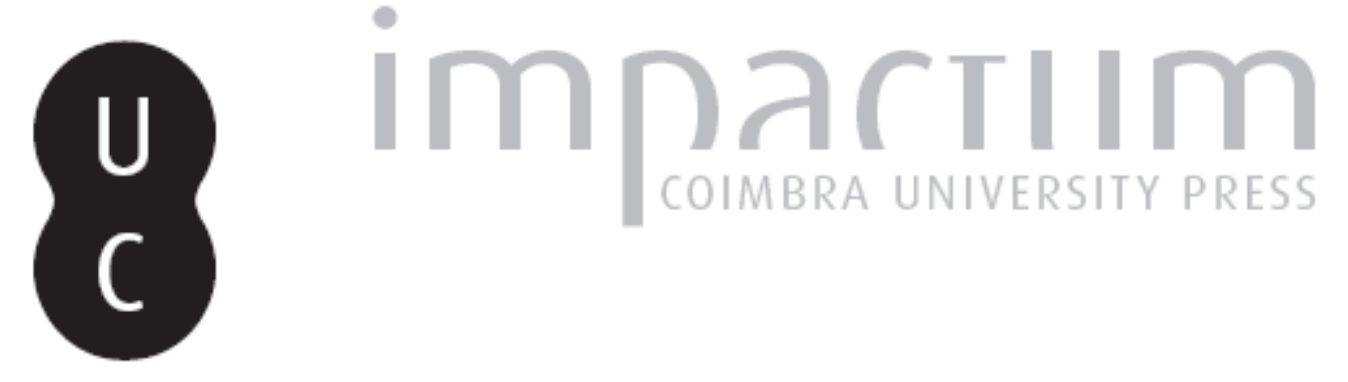

\title{
Scientific knowledge and myth
}

Autor(es): Brisson, Luc

Publicado por: Imprensa da Universidade de Coimbra

URL persistente:

URI:http://hdl.handle.net/10316.2/42247

DOI:

DOl:https://doi.org/10.14195/2183-4105_4_1

Accessed : $\quad$ 26-Apr-2023 10:41:24

A navegação consulta e descarregamento dos títulos inseridos nas Bibliotecas Digitais UC Digitalis, UC Pombalina e UC Impactum, pressupõem a aceitação plena e sem reservas dos Termos e Condições de Uso destas Bibliotecas Digitais, disponíveis em https://digitalis.uc.pt/pt-pt/termos.

Conforme exposto nos referidos Termos e Condições de Uso, o descarregamento de títulos de acesso restrito requer uma licença válida de autorização devendo o utilizador aceder ao(s) documento(s) a partir de um endereço de IP da instituição detentora da supramencionada licença.

Ao utilizador é apenas permitido o descarregamento para uso pessoal, pelo que o emprego do(s) título(s) descarregado(s) para outro fim, designadamente comercial, carece de autorização do respetivo autor ou editor da obra.

Na medida em que todas as obras da UC Digitalis se encontram protegidas pelo Código do Direito de Autor e Direitos Conexos e demais legislação aplicável, toda a cópia, parcial ou total, deste documento, nos casos em que é legalmente admitida, deverá conter ou fazer-se acompanhar por este aviso. 


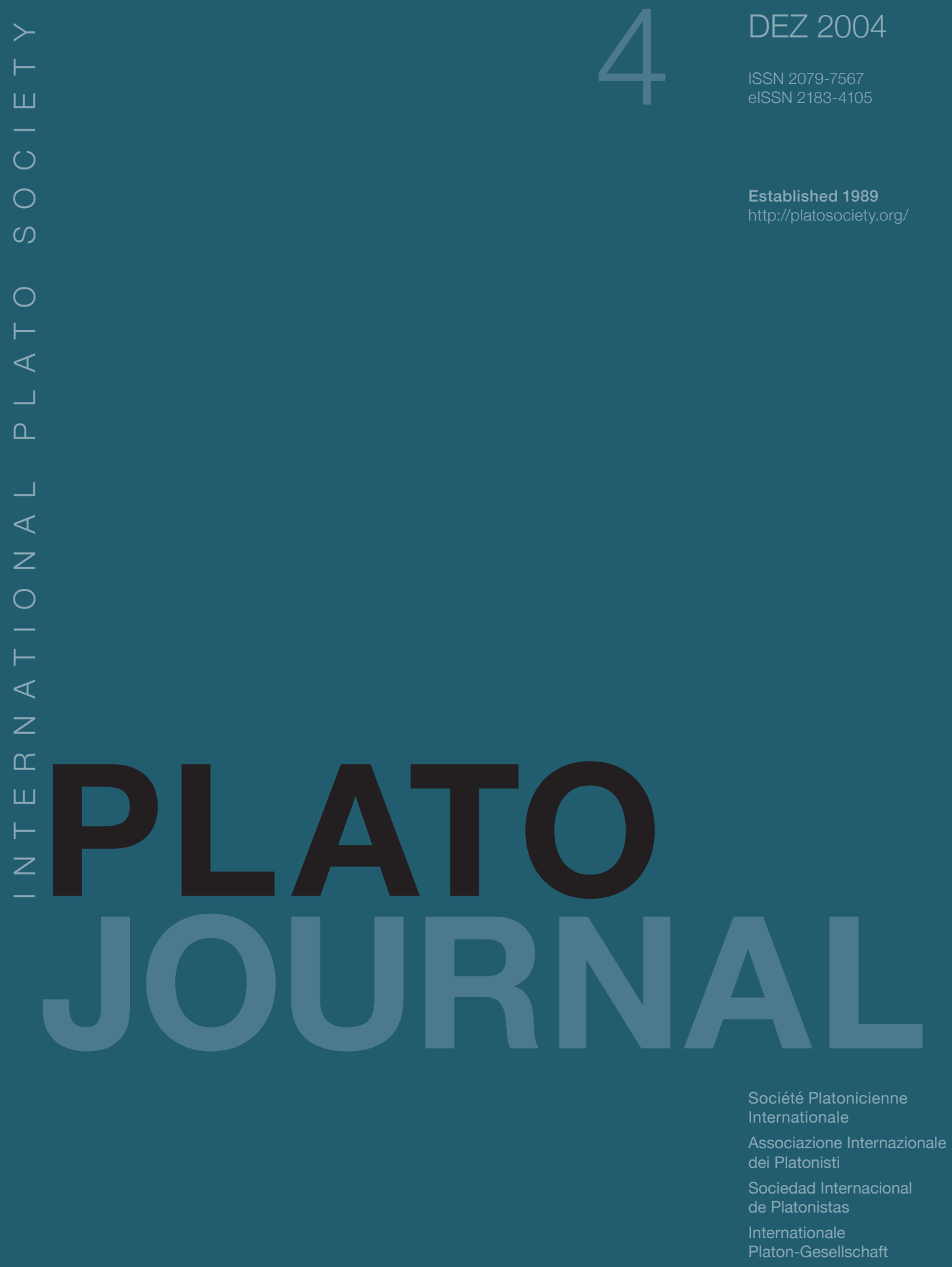




\section{SCIENTIFIC KNOWLEDGE AND MYTH}

Plato was the first Greek author to take the already-existing term mûthos and make systematic use of it, opposing it to the term logos (rational discourse), and giving it the meaning we are accustomed to give it even now, when we use the term "myth." This is what I tried to show in my book : Plato the Myth Maker, translated into English by Gerard Naddaf, University of Chicago Press, 1998.

The opposition mûthos/lógos in Plato can be interpreted as an opposition between narration and argument, on the one hand, and between verifiable and unverifiable discourse, on the other. Whereas the former opposition is based on an internal criterion, that is, the organization of its own parts, the second depends on an external criterion: discourse's relation to the object to which it is supposed to refer.

A narration relates events as they are supposed to have happened, without giving any explanation; thus, the sequence of parts is contingent, at least from a superficial point of view, since several attempts have been made to uncover a logic of narration that plays a role in myths. The only goal of a narration, at least in appearance, is, through the intermediary of the person who fashions and/or narrates it, to bring about emotional fusion between the addressee of the narration and its hero. By contrast, argumentative discourse follows a rational order (whatever definition of reason one may hold). The interconnection of its parts takes place on the model of mathematics, according to rules whose goal is to make the conclusion necessary. The person engaging in this discourse seeks rational agreement with regard to the conclusion.

In Plato, a discourse can be qualified as verifiable only if its referent is accessible to the intellect or to the senses. In all cases, truth and falsehood are defined as the appropriateness or inappropriateness of discourse with regard to its referent. Yet Plato presents myth sometimes as a false discourse, and sometimes as a true discourse; in other words, myth is an unverifiable discourse. Why is this? Because of its object. Myth speaks of the gods, demons, and mankind's fate after death. Its object is thus the soul in general, whether it be the soul of immortal living beings whose body is indestructible, like the gods and the demons, or the soul of those mortal living beings known as humans and animals. In Plato, the soul, as a reality intermediary between the sensible and the intelligible, cannot be apprehended either by the senses or by the intellect. We can thus never say that discourse on the soul is either true or false: it is true and false at the same time, and it is neither true nor false. And yet Plato tells myths, and fashions them. Why is this? 


\section{Plato tells myths and fashions them}

For Plato, as I said, myth features two defects. It is a discourse that is unverifiable, and can often be assimilated to false discourse, when it departs from such and such a doctrinal point defended by the philosopher: for instance, Zeus cannot be lubricious, violent or dishonest, since according to Plato, gods must be good. Secondly, myth is a narration whose elements are interconnected in a contingent way, unlike argumentative discourse, whose internal organization appears as necessary. This is why, in the first instance, as we see in books II, III, and X of the Republic, Plato submits myths to a radical critique, which bears upon the claim that they describe reality, and propose values attached to certain modes of behavior. Myths do not describe genuine reality, but are mere images of images, if we accept Plato's doctrine that sensible particulars are mere images of genuine reality. In addition, traditional myths present gods, demons and heroes, whom human beings should take as their models, in the process of committing reprehensible acts: they lie, fight among themselves, commit rape, etc.

Yet for all that, Plato does not renounce traditional myths (which he recommends should be censured before they are told), but alludes to them frequently in his work. What is more, he adapts some of them, and it even happens that he creates new ones, as a function of circumstances. He does so for reasons that are practical, on the one hand, and concern ethics and politics, and theoretical, on the other hand, having to do with psychology and metaphysics.

In Platonic ethics, the idea of retribution (that is, of reward or punishment) affecting the human soul plays a considerable role. Living beings -that is, beings endowed with a soul and a body- are situated within a hierarchy, at the summit of which are gods and demons, and at the bottom of which are animals. Gods and demons, whose bodies are indestructible, always remain at the same level. The human soul, by contrast, whose body is destructible, can migrate from one body to another, be they the bodies of other human beings, or even of animals. The human soul can therefore, if it is punished, descend the scale of living beings by incarnating itself in animals that are more and more vile, or, if it is rewarded, it can rise back up to assimilate itself to god, which is the aim of Platonic ethics; this rising is equivalent to a reward, and the descent to a punishment. Myth alone succeeds in describing the destiny of the human soul after its separation from a body of a specific type, and therefore its reward or its punishment, which consists in progressing towards god, or else in sinking into the animal world, becoming a lion, a dog, a serpent, or even an oyster. This explains the numerous 
eschatological myths we find at the end of important Platonic dialogues : Gorgias, Phaedo, Republic, Timaeus, etc.

Plato also has need of myth in the political arena. For him, power must belong to those who possess knowledge. Those who possess knowledge are a minority, but they must be able to make themselves understood and obeyed by the majority. To achieve these goals without using the violence needed to punish or even suppress those who break the rules or the laws, the ideal instrument of persuasion remains myth. This is true for the following two reasons: the principal myths are known to all citizens as soon as they are able to understand the ordinary language spoken by their mothers and grandmothers; in addition, the narration of myths gives rise to pleasure in those who lend their ears to them. Here are a few myths used by Plato in the context of his two most important dialogues which deal with the government of the city-state, the Republic and the Laws.

In the Republic, the myth of autochtony, which is also mentioned in the Laws, explains that all citizens emerge from the earth of their citystate as if it were their mother (Republic, III 414d-e). It serves to convince the inhabitants that the city-state is one and indivisible, although it is made up of distinct groups, as is shown in the myth of metals (Republic, III 415a-d). The myth of Gyges (Republic, II 359d-360b) gives an excellent illustration to the thesis rejected by Socrates, according to which injustice is good from the point of view of nature; if a man could remain invisible and never be detected, he would systematically commit acts of injustice.

In the Laws, myth plays a considerable role with regard to legislation. In Book IV (719c-724a), Plato examines the practice of the legislator, comparing him to the poet and the doctor. Unlike the poet, who does not hesitate to develop contradictory discourses on the same subject, the legislator must produce discourse that is not contradictory. However, even if the legislator does hold the same discourse on one and the same subject, he is not necessarily obliged to limit himself to a simplistic discourse. To illustrate what he means, Plato speaks of two doctors, who behave in opposite ways. The first one gives his patients no explanation of the malady affecting them, and brutally gives them prescriptions before moving on to another patient. The second one asks the patient and his entourage how he is feeling, and takes the time to persuade him that his prescriptions are well-founded. Similarly, the legislator's discourse can be either simple or twofold. If it is simple, it is brief, and consists of only two elements : the prescription of the law and the formulation of the penalties incurred by anyone who does not submit to it. It is lengthier when it is twofold, and the prescription of the law is 
preceded by a declaration, which usually is rhetorical or mythological, that seeks to substitute persuasion for the fear of punishment. Thus, obedience to the law must, in the first instance, be obtained through persuasion.

On an ethical and political level, myth induces the individual to obey moral rules and laws by means of persuasion, without the need to introduce the violence implied by the punishment of those who disobey the rule or the law. But myth has also a theoretical function.

On a theoretical level, myth enables the description of the destiny of the human soul. The belief that the soul has experienced an existence separate from all bodies, in the course of which it has acquired specific knowledge which it must remember in its subsequent existences, is explicitly referred to religious traditions in the Meno, the Phaedo, the Phaedrus, and the Symposium. The belief that its previous behavior is, for the human soul, the object of retribution (reward or punishment) is affirmed in several eschatological myths. Finally, the belief according to which the soul can be incarnated in various bodies of human beings or of animals is formulated in the Phaedrus and the Timaeus. Everything that has to do with the intelligible forms --which for Plato is the realm of true reality-- is, by means of these beliefs about the soul, associated with myth: the "myth" of the cave (Republic, VII 514a-517), which is completed by the "image" of the sun (Republic, VI 506d-509b), and that of the line (Republic, VI 506d-509b). It follows that myths constitute the soil in which fundamental philosophical speculations take root: those concerning the soul, and those concerning the intelligible forms. Myths thus constitute a reservoir of presuppositions for the philosopher.

Thus, Plato goes from mûthos to lógos, only to return to mûthos. He is first led to criticize the tradition represented by myth, in order to impose the triumph of science, of which philosophy is the depository and the promoter. Soon, however, he comes to recognize the need for tradition, and therefore for myth, in order to induce human beings to obey the rules that govern the moral conduct of each human being, as well as his life within the city-state. In conclusion, rational knowledge is not an illusion for Plato, but it ultimately depends on beliefs transmitted by tradition through myths.

Luc Brisson 